\title{
Natural Resources Self-Sufficiency - How to Balance Groundwater Protection and Mineral Resources Exploitation - Pleterje Case, Slovenia: Legal and Geological Aspects
}

\author{
Senko Pličanič ${ }^{1}$ Željko Pogačnik², Eva Koren ${ }^{3}$ and Goran Vižintin ${ }^{3}$ \\ 1 University of Ljubljana, Faculty of Law, Poljanski nasip 2, 1000 Ljubljana, Slovenia; (senko.plicanic@pf.uni-li.si) \\ ${ }^{2}$ Georudeko, geologija rudarjenje in ekologija d.o.o., Anhovo 1, 5210 Deskle, Slovenia; (zeljko.pogacnik@georudeko.si) \\ ${ }^{3}$ University of Ljubljana, Faculty of Natural Sciences and Engineering, Aškerčeva 12, 1000 Ljubljana, Slovenia; \\ (eva.koren@guest.arnes.si, goran.vizintin@guest.arnes.si)
}

doi: $10.4154 / g c .2021 .02$

Article history:

Manuscript received July 22, 2020

Revised manuscript accepted January 13, 2021

Available online February 28, 2021

\begin{abstract}
The purpose of this article is to showcase opportunities for local communities to demonstrate selfsufficiency with respect to natural resources (gravel and sand) in the east of Slovenia. Limitations put in place for the exploitation of mineral resources by applicable regulations in the light of groundwater protection were analysed particularly in the context of mining undertaken in an area of shallow alluvium with a shallow groundwater table. It is essential that land disturbance (from mining activity) complies with the environmental limitations imposed by both EU and Slovenian law. The study highlights the factors directly indicating the inadequacy of the applicable regulations in Slovenia in relation to mining in areas of shallow groundwater; those limitations put in place the exploitation of mineral resources as unlawful works. This article outlines how such limitations negatively affect local communities' self-sufficiency and the region with natural resources, specifically mineral resources. To this end, when selecting which alluvial plain to test, we focused on the area of the Drava and Ptuj Plain (Dravsko polje and Ptujsko polje) in Slovenia. The Drava River flows through the area in question across this alluvial plain. The artificially regulated power canal of the Zlatoličje hydroelectric power plant runs parallel to the river. Pursuant to environmental regulations, mineral resources can be exploited in these areas only up to two metres above the highest groundwater level. This criterion makes it almost impossible to pursue the additional exploitation of mineral resources in this area, as well as similar areas in the catchment area of the Danube River in Slovenia. We believe that in terms of the shared use of physical space it is necessary to change this limitation and link it directly to the percentage of exploited physical space and the application of relevant extraction technologies, which do not pollute groundwater either directly or indirectly. We also believe that the criterion put in place does not withstand expert judgment as the requirement for excavation to cease up to two metres above the highest groundwater level was not defined by means of the scientific method. The article analyses inconsistencies and puts forward measures for the ongoing eco-friendly and economically sustainable exploitation of mineral resources. As an alternative, we thus suggest implementing the EU Regulation via an act that would set out the necessary limitations, based on expert starting points arising from cartographic bases under consideration of the tetrahedral consensus-seeking methodology.
\end{abstract}

Keywords: mineral resources, groundwater protection, implementing the EU acquis
The Drava and Ptuj Plain (yellow area in Figure 1), which is discussed here, falls under two geotectonic units: the smaller part to the west encompasses the east Pohorje Massif and belongs to the eastern Alps, whereas the remaining part comprising the Slovenske Gorice Hills, Haloze Hills, Dravinjske Gorice Hills (between the Dravinja River and the Drava Plain) and the lowlands along the Drava River belongs to the Pannonian basin. The Pannonian basin is formed from Neogene sediments. Meanwhile, the Drava and Ptuj Plain is covered by Quaternary sediments.

The Drava Plain covers a large flat part of the Štajerska region on the right (west) bank of the Drava River. Broadly speaking it covers a triangle shaped area of $260 \mathrm{~km}^{2}$ between Maribor, Ptuj and Pragersko. The average altitude of the plain is 250 metres above sea level. To the east of the Drava Plain is the Pohorje Massif, to the north lie the Slovenske Gorice Hills, with the Haloze Hills and the Dravinjske Gorice Hills to the south. From the left (east) bank of the Drava River towards Ormož and extending to the east (around Ptuj), the lowlands continue as the exploitation of mineral resources. 


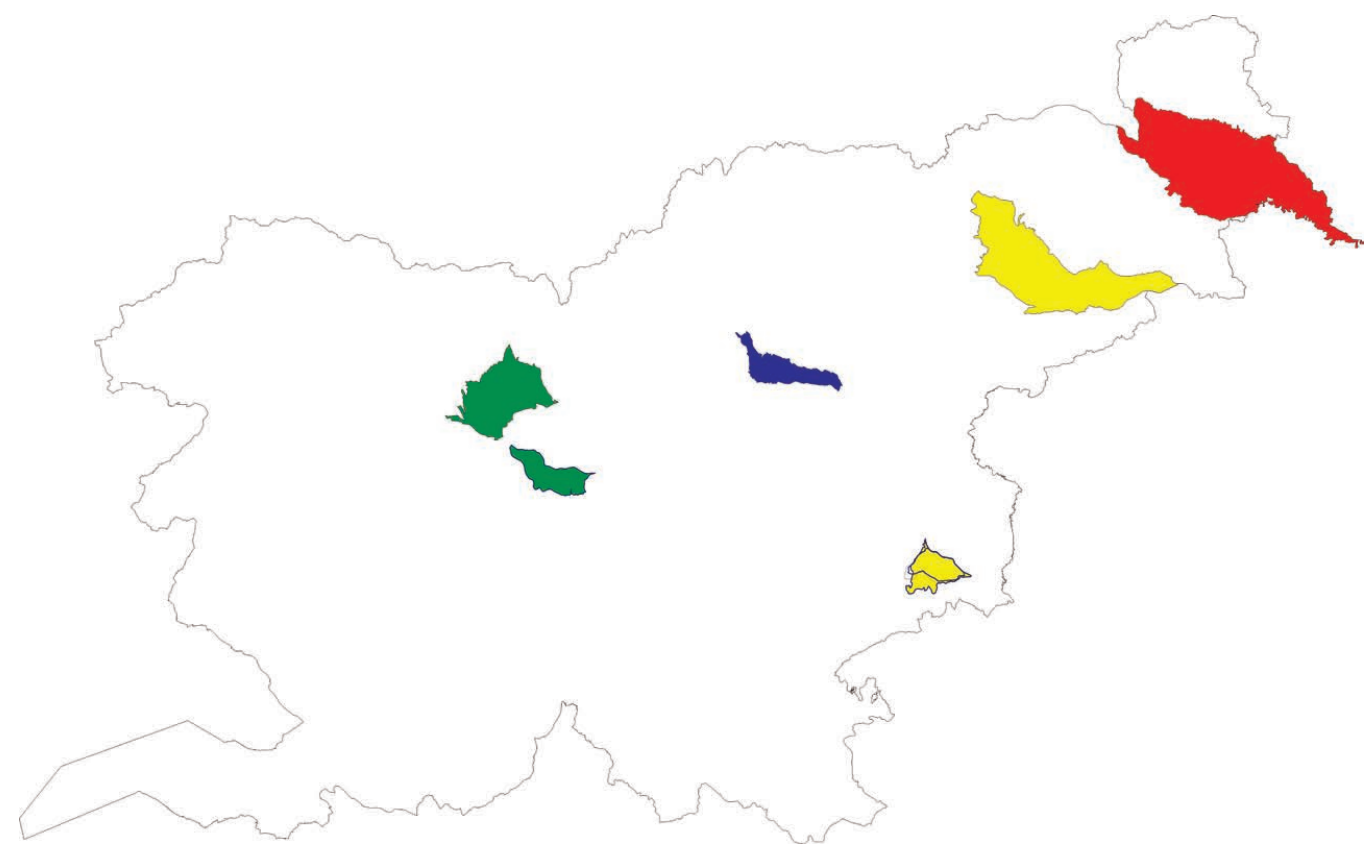

Figure 1. Important alluvial plains in the Republic of Slovenia. Red marks the alluvial area where extraction is virtually impossible, yellow marks areas where extraction is heavily affected by legislation, green marks areas that have very deep groundwater, and the blue area marks the alluvial plain that is not relevant with regard to mineral resources.

Ptuj Plain. The surface of the plain dips slightly from north west to south east. It should be noted that the flat part of the Drava Plain is not entirely flat, instead it was dissected in the Pleistocene and there are barely noticeable Holocene river terraces (ŽLEBNIK, 1982). The Ptuj Plain is a plain between Ptuj and Ormož, which makes up, together with the Drava Plain, the largest flat area in north eastern Slovenia. The divide between the plains is formed by the Drava River (near Ptuj). The Ptuj Plain transitions into the Pesniška Dolina Valley to the north where it is enclosed by the Slovenske Gorice Hills, and to the south by the Haloze Hills. The power canal of the Formin hydroelectric power plant runs parallel to the Drava River. Other water courses in the plain are the Pesnica and Zvirenčina rivers and the Sejanski Potok stream. The average altitude is 215 metres.

The pre-Neogene basement is composed of rocks of the eastern Alps that crop out on the western edge of this geotectonic unit. Neogene strata comprise Miocene and Pliocene sediments (Figure 2). Miocene sediments begin with Helvetic (MIOČ \&

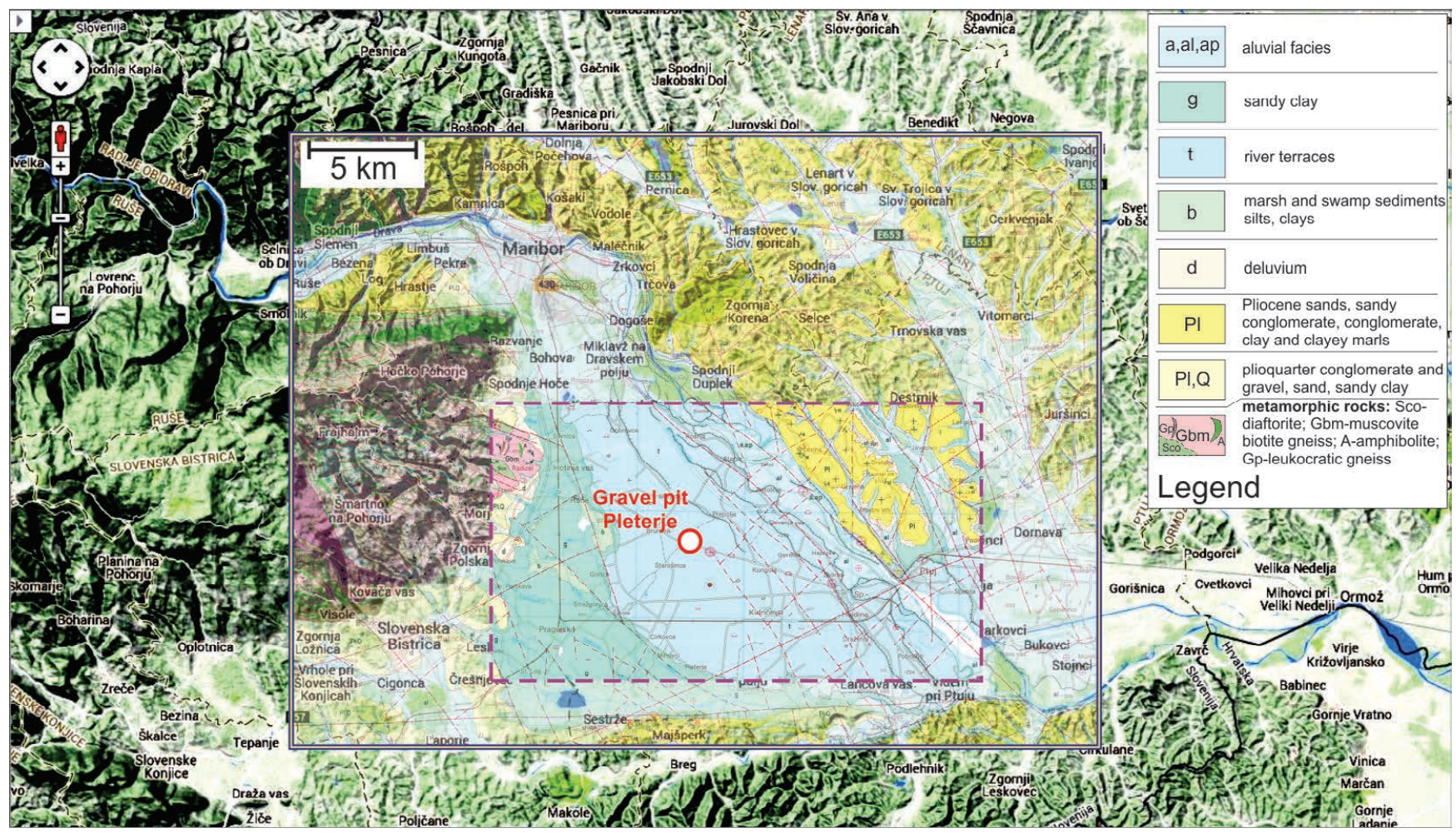

Figure 2. Study area shown on Google Earth based on the Basic Geological Map of the Maribor and Leibnitz sheets at a scale of 1:100,000 (ŽNIDARČIČ \& MIOČ, 1987); below: groundwater height in the Drava and Ptuj Plain. 
Table 1. Tabular and graphical overview of production and reserves (in metric tonnes) of mineral resources - gravel and sand for the construction industry in Slovenia (SENEGAČNIK et al, 2019).

\begin{tabular}{|c|c|c|c|c|c|c|c|c|c|}
\hline & 1988 & 1993 & 1998 & 2003 & 2008 & 2013 & 2016 & 2017 & 2018 \\
\hline Production & $3,455,355$ & $2,668,860$ & $2,440,115$ & $3,437,911$ & $4,506,076$ & $2,143,013$ & $1,833,732$ & $2,047,403$ & $1,810,666$ \\
\hline Reserves & $63,227,742$ & $39,080,471$ & $18,019,921$ & $34,241,209$ & $46,148,792$ & $34,904,839$ & $29,927,107$ & $30,535,719$ & $28,976,748$ \\
\hline
\end{tabular}

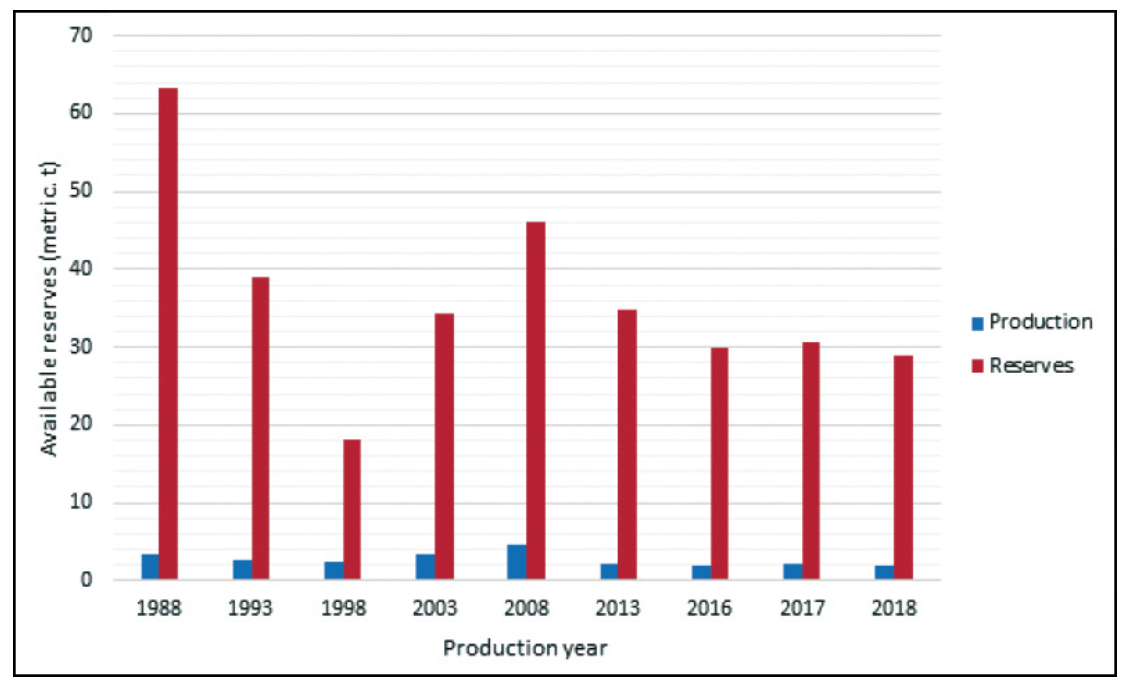

ŽNIDARČIČ, 1987) nowdays classified as Ottnangian-Karpatian conglomerate, sandstone and sandy marl. These are overlain by Badenian gravel, conglomerate, sand, marl and Lithothamnion limestone covered by Sarmatian layers of gravel, sand and sandy marl, followed by Pannonian marl, sand and gravel. Pliocene sediments are coarser grained when compared to Miocene sediments. Gravel (sometimes loosely consolidated into conglomerates) and sand prevail, while clay lenses and layers of clayey marl occur less frequently. Quaternary sediments are represented by various deposits in the Drava and Ptuj Plain: marsh sediments (silt and clay), gravel, sandy clay and alluvial, diluvial and proluvial materials along the perimeter of the plain. Plio-quaternary sediments such as gravel, clayey gravel, sand, and clay stretch along the western and southern edge of the Drava Plain. Most of the gravel (up to $70 \mathrm{wt} \%$ ) is deposited in river terraces that can reach up to 30 metres in height. The sand and sandy clay proportion is $20 \mathrm{wt} \%$ and $10 \mathrm{wt} \%$, respectively. An average sample of sandy gravel contains less than $50 \mathrm{wt} \%$ of sedimentary rock (primarily limestone and dolomite, and lesser amounts of sandstone and chert), followed by metamorphic rocks (primarily gneiss and quartzite, with lesser amounts of mica, phyllite and amphibolite), whereas igneous rocks make up the lowest proportion (mostly granite, rhyolite, diorite, gabbro, trachyte and keratophyre).

Based on the hydrometeorological data (OGRIN, 1996), the Drava and Ptuj Plain falls under the moderately continental climate of eastern Slovenia (Sub-Pannonian climate), where April averages are higher or approximately equal to October averages. The average annual precipitation is between 800 to $1000 \mathrm{~mm}$ and is therefore classified as a subcontinental precipitation regime.

Eastern and north eastern Slovenia feature several locations of deposits of industrial and energy mineral resources, as well as sites of crushed stone resources, primarily gravel deposits (pits) (Table 1).

The state sets out in its overarching strategy paper (National Mining Strategy - Mineral Resource Management, October 2018: original title: Državna rudarska strategija - gospodarjenje z min- eralnimi surovinami, oktober 2018), referred to here as "the National Mining Strategy"), under which it manages the natural resource, that the Slovenian Development Strategy 2030 also seeks to establish a self-sufficiency dynamic (DUBIŃSKI, 2013) and ensure the country's independence from foreign mineral resources. This could be achieved considering the availability of natural resources of economic value, the social acceptability of such exploitation, and the minimisation of environmental influences.

The available reserves of mineral resources (gravel and sand) ensure short-term self-sufficiency with mineral resources from the existing gravel pits and sand pits. Considering the average consumption of the past 20 years, $\left(2,705 \cdot 10^{6}\right.$ metric tonnes per annum), these reserves will provide for 11 years of balanced extraction of resources taking into account the available average reserves as of 2016. However, it is absolutely necessary to consider how to ensure that, going forward, there will be sufficient resources available, whilst taking into consideration mining operations, their economic efficiency (especially with variable expenses per unit of resource associated with non-mining processes; KUDEŁKO et al., 2013; HENCKENS et al., 2016), and the limitations arising from the problems (VOULVOULIS et al., 2017) related to implementing this piece of legislation, with which the concessionaires are bound to comply.

In the Drava and Ptuj Plain, the remaining alluvial plain extraction from sand pits takes place with hydraulic excavators, loaders und bulldozers (Figure 3). Typically, the extraction of mineral resources requires the prior deforestation of the area, clearing of undergrowth, and the stripping of the upper humus/ soil cover (from $0.3 \mathrm{~m}$ to $0.5 \mathrm{~m}$ thick) from the surface of the entire extraction area. Pedologic horizons $\mathrm{B}$ and $\mathrm{C}$ comprise a 0.5 $\mathrm{m}$ to $0.7 \mathrm{~m}$ thick layer of clayey gravel which counts as tailings in the technological process. Humus and tailings are stored to the side of the extraction area in a heap (in line with the applicable mining project) and are then used for the rehabilitation and recultivation of parts of the mineral resource exploration site (ŽELEZNIKAR, 2015). 


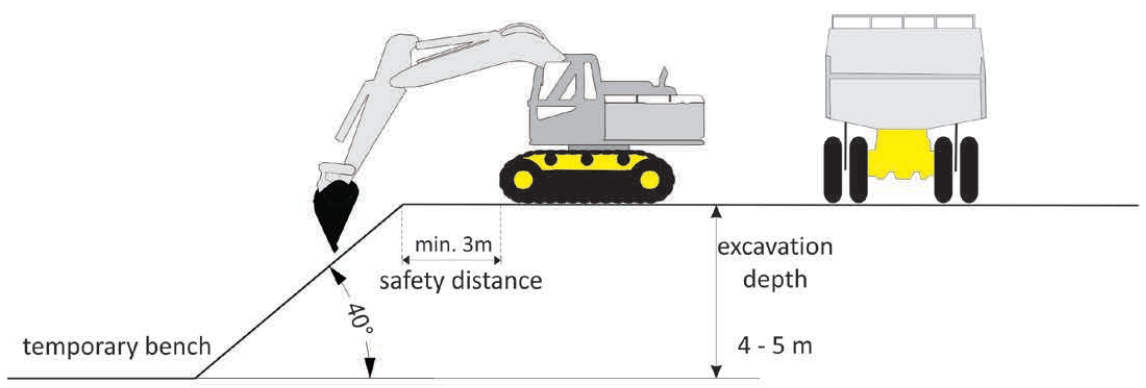

A

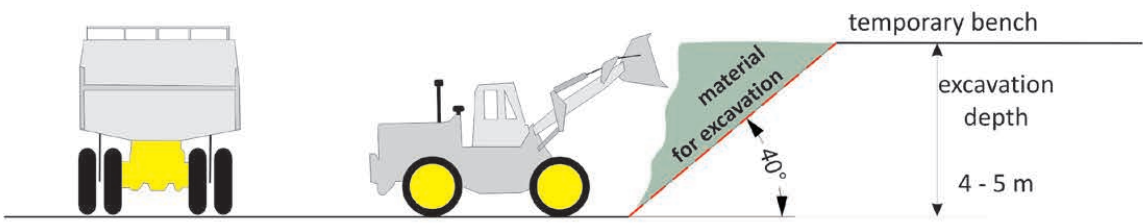

B

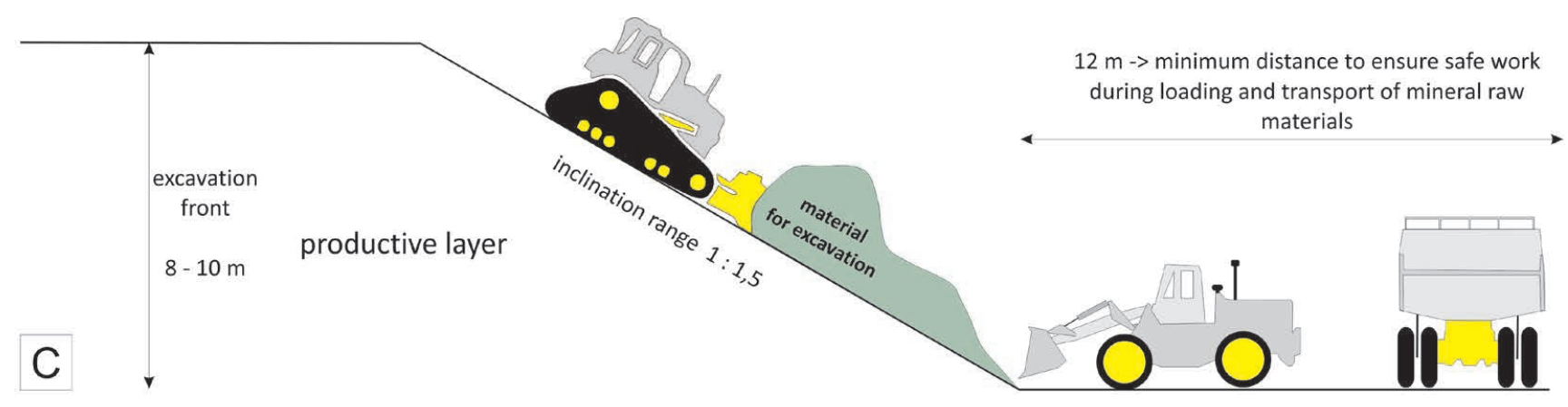

Figure 3. Excavation with hydraulic excavator (A); excavation and loading with loader (B) and excavation with bulldozer and loader (C).

We consider the concern regarding open water surfaces and the evaporation rate, which such surfaces increase, to be a prerequisite for sustainable development. Nevertheless, restrictively set criteria that allow differing interpretations of the legislation do not support commercially agile mining operations and, by extension, fail to support self-sufficiency with regard to mineral resources.

Namely, Article 8 of the Decree on the River Basin Management Plan for the Danube Basin and the Adriatic Sea Basin (Official Gazette of RS, No. 61/11, 49/12 and 67/16) specifically lays down the bans, conditions and limitations concerning groundwater usage, and the conditions for groundwater disturbances. Six paragraphs outline the conditions for groundwater usage, and two paragraphs document the conditions for exploitation of mineral substances (relating to water). Thus, in paragraph six, the Decree sets out that if the mining right for the exploitation of primary mineral resources pertains to groundwater, it shall be granted under the following conditions:

a. exercising of the mining right shall not open or increase the aquatic surface of groundwater,

b. the maximum depth of excavation must lie at least two metres above the highest groundwater level.

Paragraph seven of the same article decrees that mining activities shall involve only those substances, including explosives, which on their own, or their degradation products, shall not cause deterioration of the groundwater chemistry at the site of uptake.

It arises from Article 4 of the Mining Act (hereinafter: ZRud1), which defines mineral resources as an asset owned by the Republic of Slovenia as a natural resource, that primary mineral resources include energy, metallic, non-metallic and other mineral resources. Non-metallic mineral resources comprise:

1. mineral resources for the processing industry, including quartz and quartz sand;

2. mineral resources for construction materials and product industries; mineral resources for the construction industry including crushed stone (limestone, dolomite), all igneous and metamorphic rocks, and gravel, rubble and sand.

The Decree, ZRud-1 and the Water Act (hereinafter: ZV-1) fail to make clear when the mining right for the exploitation of mineral resources applies to groundwater. We believe that this provision of the Decree is to be interpreted as meaning that the mining right for exploitation applies to groundwater only where the exercise of the mining right for exploitation of mineral resources, i.e. mining (exploitation of mineral resources), impacts groundwater. As previously stated, the Decree specifies in Article 8 the bans, conditions and limitations on groundwater usage and conditions concerning groundwater disturbances. Thus, the main objective of Article 8 of the Decree is to protect groundwater against pollution, also in cases when pollution might be brought about due to mining operations (exploitation of mineral resources).

For the legal analysis of applicable regulations concerning the issue at hand it is important to look at Directive 2006/118/EC on the protection of groundwater against pollution and deterioration. The key is to determine whether the restrictions defined by the Decree are enshrined in this directive. Directive 2006/118/EC on the protection of groundwater against pollution and deterioration, which was adopted by the European Parliament and the 
Council of the European Union back in 2006 (hereinafter: the Directive), establishes specific measures for the prevention and control of groundwater pollution, namely:

- criteria for the assessment of good groundwater chemical status;

- criteria for the identification and reversal of significant and sustained upward pollution trends and for the definition of starting points for trend reversals.

This Directive also complements the provisions preventing or limiting inputs of pollutants into groundwater already contained in Directive 2000/60/EC, which establishes a framework for Community action in the field of water policy (the Water Framework Directive - WFD), and aims to prevent the deterioration of the status of all bodies of groundwater. The Directive 2000/60/EC establishes in this regard that Member States shall implement the measures necessary to prevent or limit the input of pollutants into groundwater and to prevent the deterioration of the status of all bodies of groundwater. The Directive does not contain any provision that would directly impose conditions for the exploitation of mineral resources with the aim of protecting groundwater against pollution. As part of the essential measures above, the directive is clear that it is up to the Member States to establish how the measures are to be implemented. Hence, the Directive does not establish that it is necessary, in order to protect groundwater against pollution, to limit the base of excavation to a minimum of two metres above the highest groundwater level.

By establishing (in the provisions of paragraph six of Article 8 of the Decree), that the mining right for the exploitation of primary mineral resources as it relates to groundwater may only be granted if exercising the mining right does not open or increase the water surface and groundwater, and that the excavation bottom must be two metres above the highest groundwater level at a minimum, the Government of the RS (hereinafter: the Government) defines that this is one of the (urgent) measures in order to prevent or limit the input of pollutants into groundwater and in order to prevent the deterioration of the status of all bodies of groundwater in Slovenia.

Limiting the exploitation of mineral resources defined by the Decree, therefore, is not a requirement set out by the relevant directive. Whether such limitations are compliant with the Act on the Government of the Republic of Slovenia, the Water Act, and the Constitution, and how the arrangement in the Decree affects the existing concessionaires are analysed below.

The paper also analyses the constitutionality and legality of exploitation limitations as set out by the Decree and their impact on self-sufficiency and proposes solutions for not only groundwater protection but also the exploitation of mineral resources, and thus self-sufficiency.

As Pettersson and others show (PETTERSON et al., 2015) in some other EU countries (Sweden and Finland) the environmental aspects of mineral resource exploitation (the impact of mining operations on the groundwater included) are being assessed through environmental impact assessment procedures (EIA) on the case by case basis. This paper proposes that the same approach is also used in Slovenia.

\section{MATERIAL AND METHODS}

The manner in which the above measures, which aim to prevent or limit the input of pollutants into groundwater, and prevent the deterioration of the status of all bodies of groundwater, are to be carried out therefore falls entirely under the competence of the Member States, including Slovenia. Slovenia implemented the requirements of this Directive in various ways, for example by adopting a relevant Decree, thus also with the provision under paragraph six, Article 8 of the Decree.

This study focuses on the Drava and Ptuj Plain as the Decree strongly affects future concessions concerning the extraction of mineral resources in this particular area. It should be noted that the same implementation in an area with a similar hydrogeological status would lead to the same issues that arise in the Drava and Ptuj Plain. To prove the uneven depth of groundwater present,

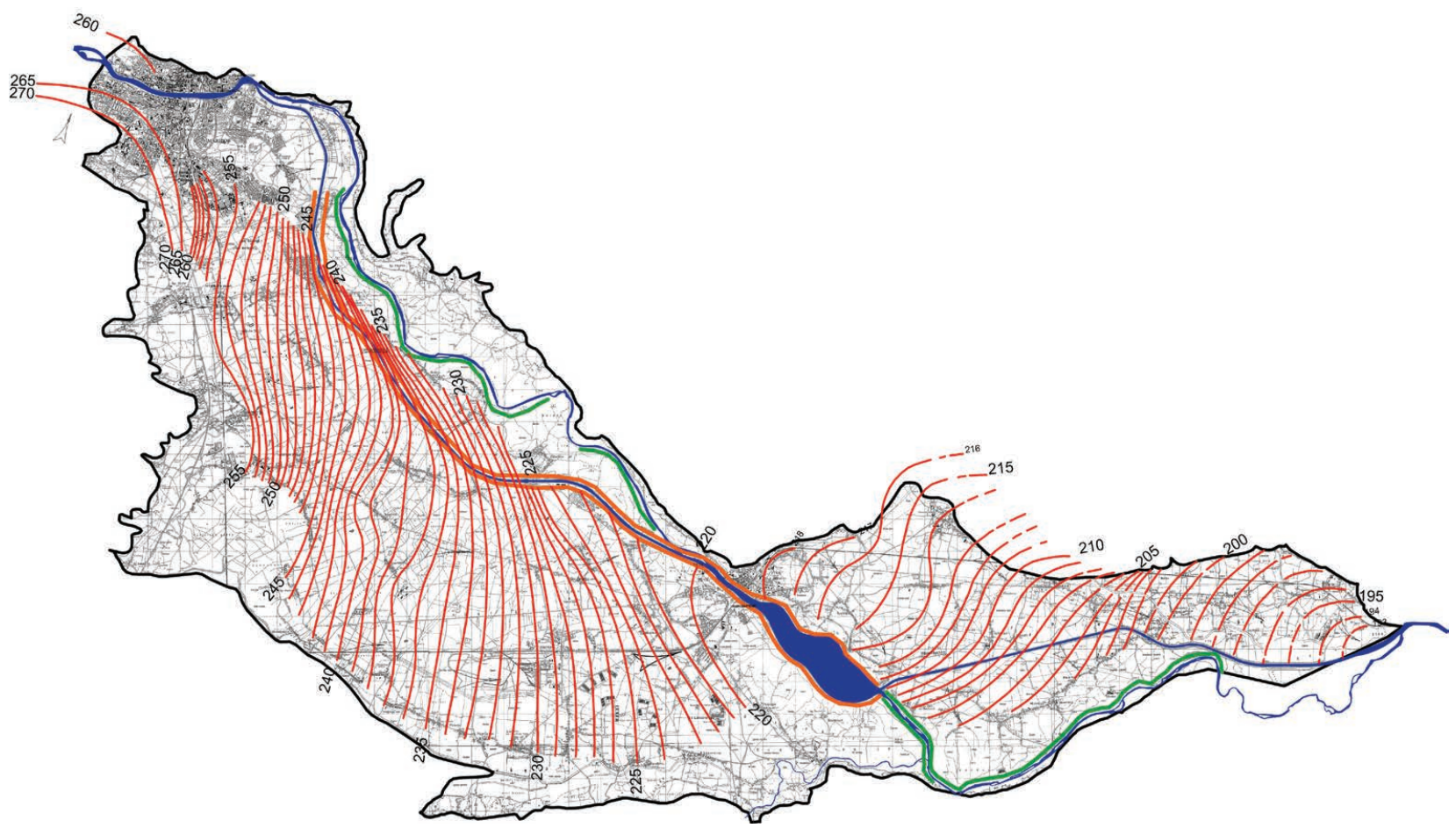

Figure 4. Interpretation of groundwater level measurements. 
we applied the data from exploration wells - piezometer measurements and pumping tests.

The Drava and Ptuj Plain has been subject to numerous hydrogeological tests conducted in the fluvioglacial aquifer (BREZNIK \& ŽLEBNIK, 1961; ŽLEBNIK, 1982; SUPOVEC, 2004; TANCAR et al 2009 a, b; ČENČUR et al., 2013; VUKELIĆ $\&$ VULIĆ, 2014). The layers of the Quaternary fill are highly permeable for water. The coefficient of permeability of the Pleistocene sandy gravel fill in the Drava Plain ranges in various locations from $3.6 \times 10^{-5} \mathrm{~m} / \mathrm{s}$ to $8 \times 10^{-2} \mathrm{~m} / \mathrm{s}$. The general direction of the groundwater flow (Figure 4 or 5) is based on the measurement of groundwater levels (BRILLY \& VIŽINTIN, 2011) for water resource management purposes (BRILLY \& VIŽINTIN, 2011). There are two different approaches involved, the first one (Figure 4) relies solely on interpolation, and the second one (Figure 5) is a result of modelling.

Groundwater flow runs from west/north-west towards east/ south-east. The area is recharged by rainfall from the hilly outskirts of the Pohorje Massif and the Haloze Hills. Based on these measurements it is possible to determine the fluctuation of the thickness of the unsaturated zone from a few metres to a little over 10 metres. Similarly, the mathematical model (ČENČUR et al, 2013) indicates that lateral recharge occurs mostly from the west/north-west, i.e. the Pohorje Massif, and in lesser quantities from the south, i.e. the Haloze Hills. The study area is also subject to recharge from rainfall (Figure 4 and 5).
To create the model used to test the proportionality principle, we used Visual ModFlow 2011.1, version 4.6.0.161, which applies the ModFlow (USGS) numerical groundwater flow model. The numerical model is based on solving the partial-differential equation of flow through a porous medium by using a finite-difference method. The entire plain was divided into a rectangular grid containing $500 \times 500$ cells $(91 \mathrm{~m} \times 62.6 \mathrm{~m})$. On the western and southern outskirts of the Drava Plain we set recharge boundaries that are equivalent to Neumann's boundary condition. The starting value was set at $20,000 \mathrm{~mm} / \mathrm{m}^{2}$ for each of them. The model calibration process is depicted on the flowchart in Figure 6.

In accord with Figure 6, the model was calibrated using a tool referred to as PEST. To achieve the required calibration, the model was run hundreds of times. In cases in which PEST improvements did not generate the condition NORM RMS $<5 \%$, we changed the model inflow areas and the $\mathrm{k}$ areas in the model. PEST is a programme that is used for automatic model calibration and runs on the principle of considering certain areas in which it changes the values of selected physical parameters (in our case we chose hydraulic conductivity) set by the modeller. Throughout the optimisation, the programme monitors modelto-measurement residuals. The step involving a change is determined based on the model stability analysis which is either performed beforehand by PEST or determined by the user. Typically, PEST requires hundreds or thousands of mathematical model runs for which it tracks the residual changes. The combination of

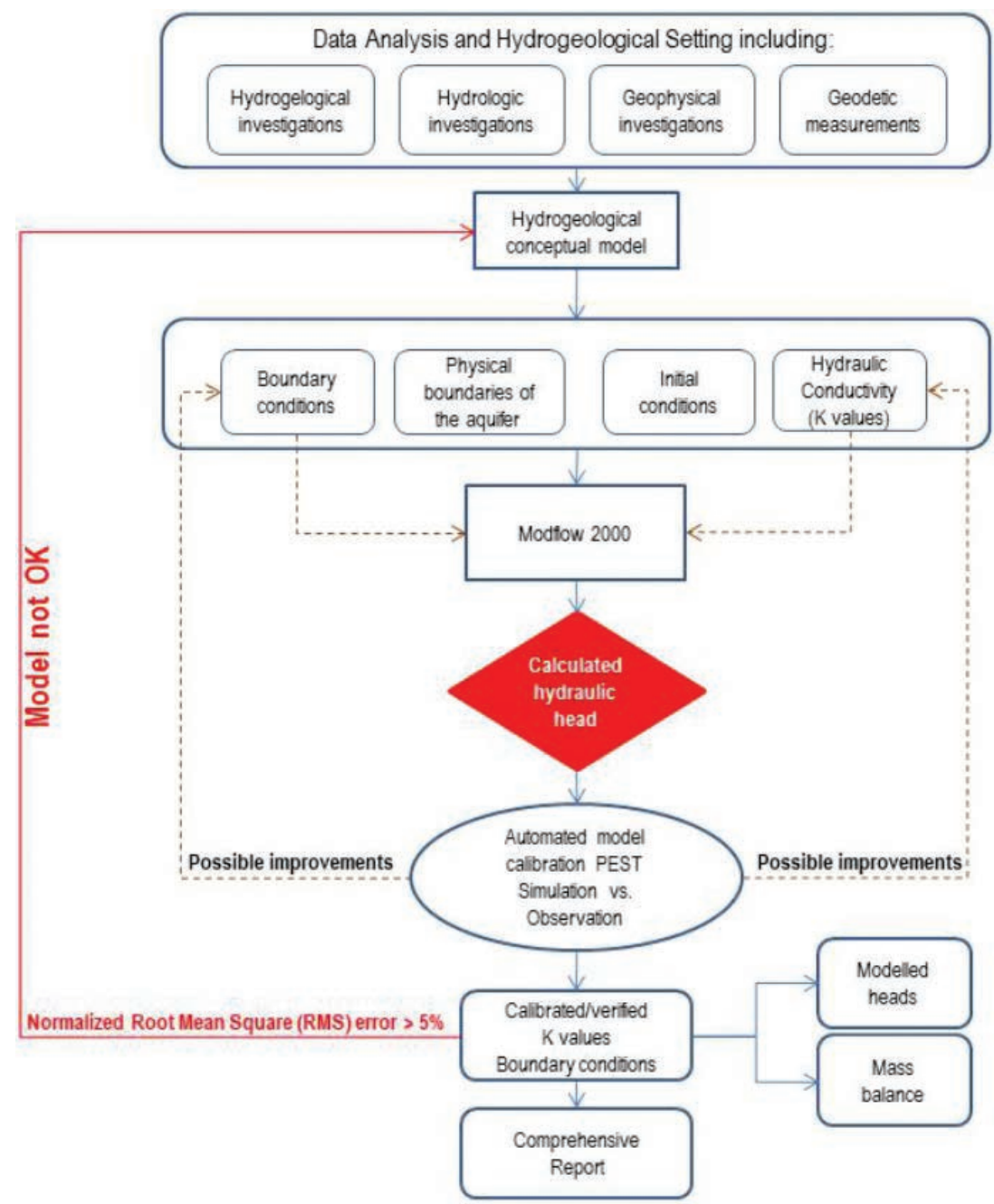

Figure 5. Modelled groundwater levels and recharge areas from the outskirts of the Drava and Ptuj Plain. 


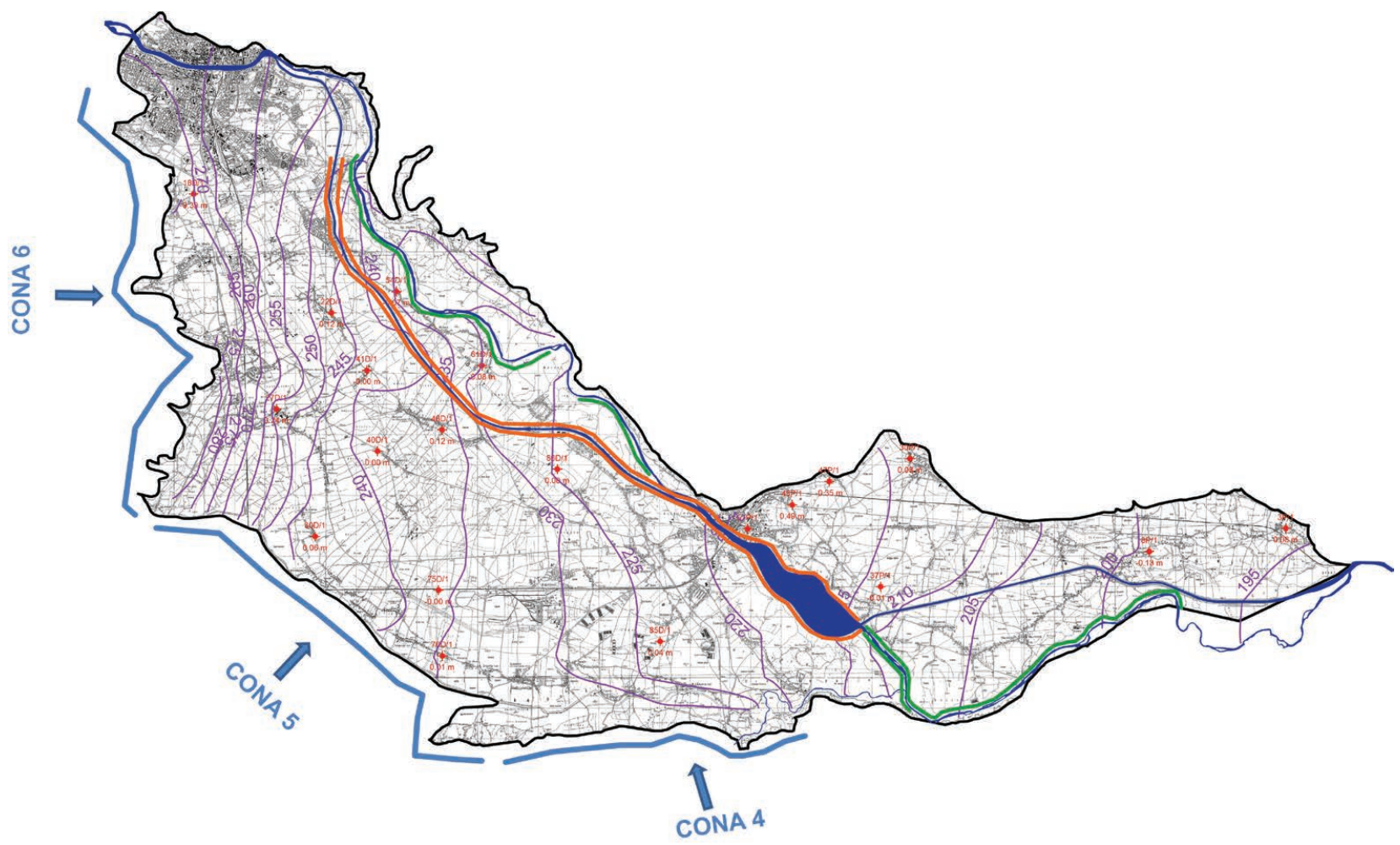

Figure 6. Flowchart depicting the model calibration process for groundwater flow in the Drava and Ptuj Plain (ČENČUR et al., 2013).

relevant values of fluctuating parameters which will generate the best match of model-to-measurement piezometrics is generated at the end of the process as the calibration result. During calibration, the user can exclude specific values from the calibration and assign other values which the user deems to be correct. In the Drava and Ptuj Plain the model was calibrated both with PEST and manually; occasionally some parameters that were left unchanged in PEST were later changed during manual calibration in order to generate better results.

The Normalised Root Mean Squared (NORM RMS) is the RMS divided by the maximum difference in the observed head values. The Normalised RMS is expressed as a percentage and is a more representative measure of the fit than the standard RMS, as it accounts for the scale of the potential range of data values. For example, an RMS value of 1.5 will indicate poor calibration for a model with a range of observed values between 10 and 20, but it will indicate an excellent calibration for a model with a range of observed values between 100 and 200. However, the Normalised RMS value for the first model would be $15 \%$, while the Normalised RMS for the second model would be $1.5 \%$. In the second situation, the Normalised RMS values clearly indicate that the second model provides a good fit between the calculated and observed values (WATERLOO HYDROGEOLOGIC, 2011).

\section{RESULTS AND DISCUSSION}

Having started out with a model that initially featured three areas of hydraulic conductivity, the final model had 26 areas of hydraulic conductivity (Figure 7) for which we were able to change the values of $\mathrm{k}$ (Figure 7) by using PEST or manually, considering the restrictions of the pumping tests.

It can be observed that the two methods of interpretation produce markedly different values for the same hydrological status
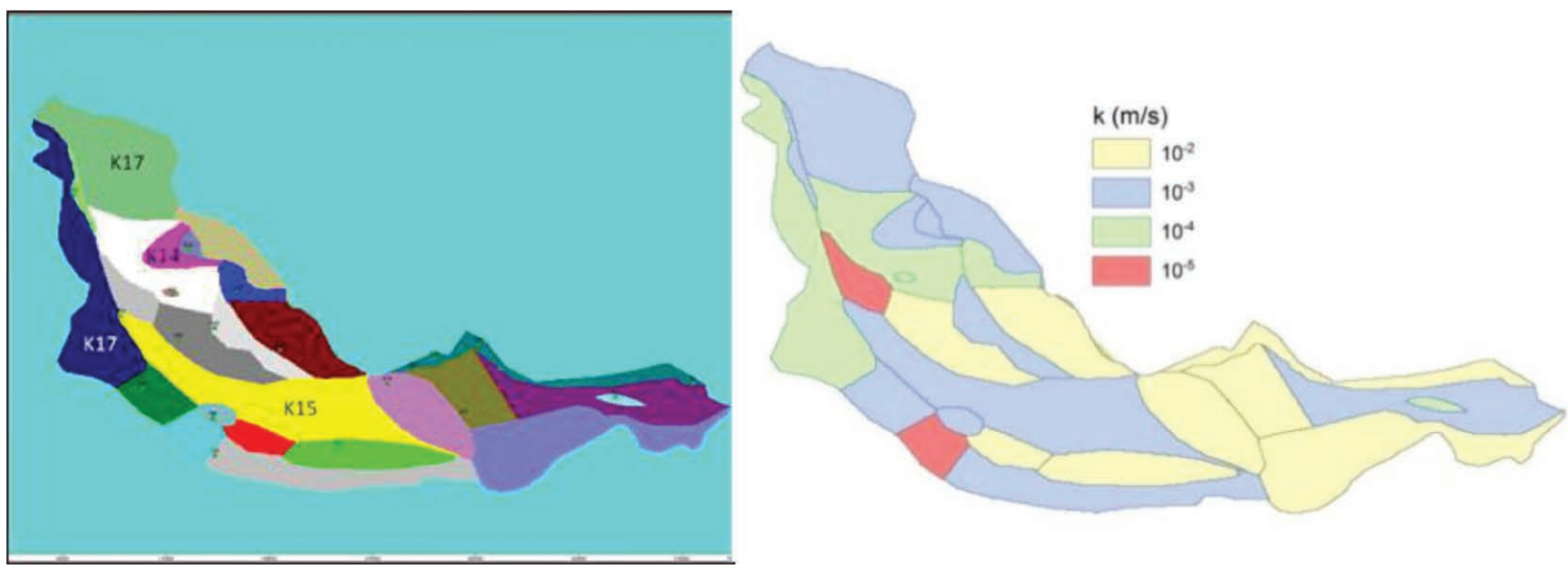

Figure 7. Areas with varied hydraulic conductivity. The values range from $3.6 \times 10^{-5} \mathrm{~m} / \mathrm{s}$ to $8 \times 10^{-2} \mathrm{~m} / \mathrm{s}$. 
(Figures 4 and 5). The interpolation method plots water levels without considering different physical groundwater flow parameters (Figure 4), whereas these parameters are considered in the mathematically modular method (Figure 5).

The different methodologies (Figure 4 and 5) result in different groundwater level assessments and this issue of methodology must be appropriately addressed in the legislation, which is, as shown below are inadequately formulated and thereby impede groundwater protection, and reasonable land disturbances.

The Government established (with full autonomy) in the provisions of paragraph six of Article 8 of the Decree - by establishing that the mining rights for the exploitation of primary mineral resources as it relates to groundwater may only be granted if exercising the mining rights do not open or increase the water surface and groundwater, and that the excavation base must be a minimum of two metres above the highest groundwater level. This is one of the (urgent) measures in order to prevent or limit the input of pollutants into groundwater and in order to prevent the deterioration of the status of all bodies of groundwater in Slovenia.

The limitations concerning exploitation of mineral resources as defined by the Decree, and established above, are not a requirement that would arise from the said directive. Whether these limitations are in compliance with the Government of the Republic of Slovenia Act, the Water Act and the Constitution are analysed below.

I.

The Decree is a regulation enacted by the Government in which it laid down the water management plan for the Danube Basin and the Adriatic Sea Basin.

Pursuant to provisions 54 to 61 of the Water Act, the state manages waters by following a national water management programme and plans were designed for the water management for both river basins.

Having regard to the provisions of Article 55 of ZV-1, the water management plan, inter alia, includes stipulating the possible types of use of water and marine assets, including a determination of conditions for or restrictions on use and other encroachments on water or marine assets.

ZV-1 defines natural and artificial public water assets as water and marine assets. In this context, natural public water assets are inland waters (inland waters means all standing or flowing water on the surface of the land, and all groundwater on the landward side of the baseline from which the breadth of territorial waters is measured), and (their) water land. Artificial public water assets are water land which is formed as a result of the relocation or regulation of a natural watercourse, the damming of running waters, the extraction or exploitation of mineral resources, or a similar type of encroachment in physical space which can be intended for general use.

With this provision, ZV-1 thereby authorises the Government to stipulate by way of the water management plan (also) the conditions or limitations for encroachment in water assets (which also includes groundwater).

We believe that this provision of ZV-1 must be interpreted as an authorisation given to the Government to lay down in both river basins, not only the conditions and limitations for encroachment on water assets which are already defined by ZV-1 (among which there is no provision that pertains to the exploitation of mineral resources), but also other conditions and limitations for encroachment on water assets, as long as this is necessary to achieve the water management objectives, i.e. protection of groundwater against pollution, inter alia.

The Government adopted the Decree based on Article 55 of ZV-1 and established that other such conditions and limitations of encroachment on water assets may, in line with the aforementioned provision of the Decree, apply to, among other things the exploitation of mineral resources, if in the course of this (meaning in the course of mining works pursuant to ZRud-1) there might occur encroachments on groundwater.

Such conditions and limitations which may, as stated, also apply to the exploitation of mineral resources, are directly associated with the formulation in ZRud-1 that the landowner must obtain, in order to be able to exploit mineral resources located in or on the landowner's land, a mining right for the exploitation of mineral resources. This legislation requiring a mining right for the exploitation of mineral resources (based on a concession) to be obtained, means that the manner in which property is acquired and enjoyed is set by the legislator pursuant to Article 67 of the Constitution, so that the economic, social, and environmental functions of the land area are preserved.

The stipulation (in the Decree) that the holder of the mining rights for the exploitation of mineral resources may conduct mining works in such a way that the deepest excavation is at least two metres over the highest groundwater level, in our opinion regulates the manner of exercising the mining right for the exploitation of mineral resources.

\section{II.}

In view of the provision of Article 21 of the Act on the Government of the Republic of Slovenia, the Government may govern and analyse in detail by way of an act or another regulation of the National Assembly specific relationships considering the purpose and criteria arising from the act. It is only on the grounds of an explicit authorisation under the act that the Government may also regulate by way of decree the manner of exercising the rights and obligations of citizens and other persons.

It arises from the principle of legality concerning the operation of the executive and administrative branch of authority (the Government and state administration), which is established by the Constitution in Article 120, that the operations of all those state bodies issuing and implementing general regulations must be legally dependent regarding substance, and may only technically supplement, analyse and describe the act through their regulations. It must not in any way interfere with its substance, as in this case the legislative functions could pass to the Government or the state administration.

Pursuant to the customary constitutional and legal practice, the principle of legality shall be weighed with particular attention to prevent executive bodies from independently laying down rights and obligations by regulating social relationships on a primary level. By the provision of Article 87 of the Constitution, the constitution-maker explicitly stipulated that the rights and obligations of citizens and other persons, and their limitations, can be defined by the National Assembly only through a relevant act. The phrase rights and obligations in the provision of Article 87 involves not only rights (or obligations) from the Constitution, as the provision of Article 87 does not use the phrase human rights and fundamental freedoms. Instead, the term rights also encompasses legal rights that are not directly steeped in the Constitution (this also includes the right to the exploitation of mineral resources). As mentioned, it is only with explicit authorisation 
arising from the act that the Government may regulate, by way of decree, the manner of implementing the rights and obligations of citizens and other persons.

III.

The provision of Article 55 of ZV-1 (or any other provision of ZV-1 or any other act) contains no explicit authorisation for the Government to regulate the manner of the exercising of the mining right for exploitation in the event that it should apply to groundwater (i.e. that it could impact groundwater). The said provision merely authorises the Government in general to set the condition or limit the use and other encroachments on water or marine assets in both water areas by means of a water management plan.

We therefore opine that with the provision of Article 8 of the Decree, the Government has acted in conflict with Article 21 of the Act on the Government of the Republic of Slovenia, and in conflict with Article 153 of the Constitution from which it clearly arises that the Government may regulate the manner in which the rights and obligations of citizens and other persons are exercised based only on an explicit authorisation arising from the Act. This leads us to conclude that the Decree is illegal and in conflict with the Constitution.

If no such authorisation arises from the Act, the manner of exercising rights and obligations can be set out only by the Act itself. In the case at hand, the principle of legality would be complied with by way of an arrangement in which the Act (ZV-1) would outline the fundamental substantive framework for laying down the manner of exercising the mining right for the exploitation of mineral resources, and the Government would, based on such legal provision, stipulate a detailed manner regarding the exercising of the exploitation mining right.

We also believe that provision 55 of ZV-1 conflicts with Article 153 of the Constitution as it fails to stipulate any criteria, i.e. a substantive framework, for the Government to consider when laying down conditions or limitations of use and other encroachments on water or marine assets.

As was clarified earlier, it arises from the principle of legality concerning the operation of the executive and administrative branch of authority, (the Government and state administration), which is established by the Constitution in Article 120, that the legislator must stipulate, provided that the legislator authorises the Government to issue an implementing regulation, clear-cut criteria and a substantial framework, based on which the Government shall issue such an implementing regulation. In doing so, the Government may only technically supplement, analyse and describe the Act through its regulations. It must not in any way interfere with its substance, as in this case the legislative functions could pass to other state bodies.

\section{IV.}

As mentioned above, by making provision (in ZRud-1) that the landowner must obtain mining rights for the exploitation of mineral resources in or on the land (based on a concession), the legislator determined the method of property enjoyment with the purpose of ensuring its ecological, social, and economic function in line with the provision from Article 67 of the Constitution. By requiring (with the Decree) that the holder of the mining right may perform mining works to exploit mineral resources in a way to ensure that the deepest excavation is at least two metres above the highest groundwater surface, the Government, in our opinion, regulated the mining right for exploitation of mineral resources unlawfully and in violation of the Constitution.

The afore-mentioned legal arrangement represents a determination of the method of property enjoyment pursuant to Article 67 of the Constitution. This determination constitutes various limitations of the freedom to property, which are indispensable for ensuring the ecological, social, and economic function of the property. This, therefore, constitutes limitations to the freedom to property that are necessary in order to protect the environment and the interests of other owners.

There is established constitutional case law in Slovenia with regard to this issue. The legal order determines what is subject to private ownership and what are the protected property entitlements by considering economic and social relationships. In that regard, the legal order must observe the purpose of the constitutional guarantee of ownership, which means ensuring and implementing individuals' freedom. At the same time, property as a legal institution depends on the functions conferred by the legal order. The fact that an individual is not limited in exercising their property entitlement, but must observe the interests of other community members and the community in general, falls within the concept of ownership rights according to Roman Law.

The constitutions of democratic countries protect the ownership right as a special form of substantive protection of human freedom, which should, together with other constitutional rights, ensure the possibility of the freedom, satisfying vital needs and personal development within society. At the same time, the freedom of individuals with regard to ownership cannot be unlimited and linked only to one individual-the owner. Instead, the exercise of this right must observe the interests of other members of the community as well.

These conclusions were also taken in consideration in the Constitution. In general, the right to private property is provided for with Article 33 of the Constitution. Article 67 of the Constitution states that the law provides for property acquisition and enjoyment in a way that ensures its economic, social, and ecological function. In addition, this Article includes the powers granted to the legislator to determine the content of the right of ownership within the functions of this right. Therefore the provisions set out in Articles 33 and 67 of the Constitution are inherently linked, and must be observed by the legislator in providing specific expression of the content of the right to ownership.

Therefore, the right to ownership, provided for by Article 33 of the Constitution, cannot be examined without Article 67 of the Constitution, which addresses the economic, social, and ecological function of property. Article 67 of the Constitution follows the assumption that, in addition to the individual function, property must also have a function of serving the entire community. The right of the owner must also serve to exercise the freedom and personal development of others or the entire community. Article 67 of the Constitution allows and requires the legislator to determine the content of the property.

The Constitutional Court's position is that in cases where natural resources are in question, determining the method of exercising the right of ownership does not necessarily interfere with Article 33 of the Constitution, and that instead, such limitations fall within the social attachment of property.

This means that the legislator, based on an authorisation from Article 67 of the Constitution, determines the content of the right to private property for single natural resources and assets 
(forests, waters, mineral resources etc.) which are protected by Article 33 of the Constitution.

Thus, determining the method of property enjoyment according to Article 67 of the Constitution does not necessarily interfere with the right to private property from Article 33 of the Constitution, although it does, to some extent, limit the individual's freedom in connection to property, or, in other words, it does not limit the individual's freedom in connection to property, despite the fact that it removes certain property entitlements from the constitutional protection.

However, the authorisation from Article 67 of the Constitution is limited. In case the legislator exceeds the limit, this is no longer considered a determination of the method of property enjoyment; instead, it is considered an interference with the right to private property. Such intervention may be allowed if it passes a rigorous constitutional review according to the so-called proportionality test. In the opposite case, such intervention is not allowed. The limit depends not only on the nature of the object of property, but also on the type of obligations that were imposed on the owner by the legislator in determining the method of property enjoyment.

In our opinion, any obligation set out in the process of determining the method of property enjoyment is indisputable, as long as it does not, in the implementation of one of the property functions (economic, social or ecological), reduce the value of the object or its yield for the owner. Any other obligation is considered an interference with the right to private property, even if such interference is allowed.

An interference with the right to private property is allowed in some cases as stated in Paragraph 3 of Article 15 of the Constitution. Based on Paragraph 3 of Article 15 of the Constitution, human rights may only be restricted in cases determined by the Constitution and if they are restricted by the rights of others. According to established constitutional case law, human rights and fundamental freedoms may be restricted if the legislator follows a constitutionally allowed objective and if such limitation is in line with the principles of the rule of law (Article 2 of the Constitution), specifically with the principle forbidding excessive state interventions (general principle of proportionality).

An assessment of the possible excessiveness of intervention is performed by the Constitutional Court based on the proportionality test. This test includes an assessment of three aspects of the intervention:

1. Is the intervention urgent (necessary) to attain the objective pursued?

2. Is the intervention under assessment suitable to attain the objective pursued, meaning is it actually possible to attain this objective with the intervention?

3. Is the severity of consequences of the assessed intervention in the affected human right proportionate to the value of the objective pursued or the benefits that will follow (the principle of proportionality in its strict sense or the principle of proportionality)?

Only if the intervention passes all three aspects of the test is it considered constitutionally allowed.

When determining the method of property enjoyment, meaning determining limitations that are necessary to protect the environment and interests of other owners, especially when such limitations constitute an interference with the right to private property, the legislator (and the Government, if authorised by the legislator) must observe the proportionality principle.
Given the regulation from the Constitution and constitutional case law, we are of the opinion that the provision (in ZRud-1) stating that the landowner must obtain mining rights for the exploitation of mineral resources in or on the land (based on a concession) falls within the framework of determining the method of property enjoyment, which does not constitute an interference with the right to private property (Article 33 of the Constitution), despite limiting the individual's freedom in connection to property to some extent.

However, the provision in the Decree stating that the holder of the mining right is allowed to perform mining works to exploit mineral resources in a way to ensure that the base of any excavation is at least two metres above the highest groundwater surface constitutes, in our opinion an interference with the right to private property (Article 33 of the Constitution), since it imposes obligations on landowners which reduce the value or yield from the land. In addition to reducing the value or yield from the land (there were no such limitations in place before the Decree was implemented which means that the owner was able to excavate significantly higher quantities of mineral substances when exercising their mining rights), this obligation, considering that groundwater in the territory of Pomurje flows three metres below ground, makes it effectively impossible for the customer to perform business operations to exploit mineral resources.

Furthermore, we believe that such interference with the right to private property is not allowed, since it fails in our opinion, to pass the review according to the so-called proportionality test.

As mentioned before, the legislator (or the Government acting on the basis of an explicit authorisation in the law), is obligated, in accordance with Article 67 of the Constitution, to define the content of the right to private property for single natural resources or assets (forests, waters, mineral resources etc.). Moreover, the legislator (or the Government acting on the basis of an explicit authorisation in the law), is obligated, in accordance with Articles 5 and 70 of the Constitution, to draw acts and define terms to exploit natural assets, terms for the use of land, and terms and methods of performing business and other operations with the purpose of providing for a healthy living environment.

The determination of terms applicable to the exercise of the mining right to exploit mineral resources complies with the above-mentioned constitutional provisions. This means that the Government (in case there was legal basis) or the legislator (if such legal basis was defined by the legislator in ZV-1) would have a constitutional basis for determining that the holder of the mining right is allowed to perform mining works to exploit mineral resources in a way as to ensure that the maximum depth of excavation is at least two metres above the highest groundwater surface, and would thus also have a constitutionally allowed objective to interfere with the right to private property.

As the next step, it must be assessed whether the limitation in question is in line with the general principle of proportionality.

We are of the opinion that the limitation of the maximum depth of excavation to two metres above the highest groundwater surface for the entire territory of the country (the Decree is valid for both the water bases, meaning for the entire territory of the country) is not an urgent action which would contribute towards attaining the objective pursued, that is, the protection of groundwater from contamination. It is also not necessarily true that such a measure would actually contribute to attaining the objective of such limitation (meaning effective protection of groundwater from contamination). In our opinion, an assessment of the measures necessary to protect groundwater from contamination due 
to mining works (when exercising the mining right to exploit mineral resources) should be performed separately based on the data on groundwater reserves below a particular territory (their depth). Reliable and accurate data on groundwater reserves are only attainable by drilling test wells, which would reveal the actual depth of groundwater in a particular location. Only once such data are available can the measures for the protection of groundwater be assessed. Moreover, suitable measures should be defined by weighing two concepts-protection of groundwater and protection of the right to private property. With regard to this, the severity of the consequences of the interference with the right to private property should be proportionate to the benefits that will follow such interference.

With regard to questions on whether or not the intervention is urgent (necessary) to attain the objective pursued and whether or not the intervention under assessment is suitable to attain the objective pursued, (meaning that it is actually possible to attain this objective with the intervention), we are of the opinion that there are other more moderate measures available that do not interfere with ownership rights to such an extent and would contribute towards attaining the objective pursued and at the same time meet the criteria of proportionality in a more strict sense (meaning that the interference with the right to private property is proportionate to the benefits following such interference), for example:

- setting the limitation of the maximum excavation depth to less than two metres (based on the data on groundwater reserves and other specific circumstances, retrieved on a case-by-case basis);

- establishing the mandatory use of modern mining technology which prevents the risk of contamination of groundwater while performing mining works.

Considering this, we believe that the Decree is also in violation of the Constitution because the limitation on excavation depth to at least two metres above the highest groundwater surface is an interference with the ownership right, which is not allowed by the Constitution.

In case that the legal basis for the limitations of ownership rights in question would be defined by law and by the Government implementing regulations, issued on the basis of such law, and in case that these limitations would pass the proportionality test, such interventions would be constitutionally allowed, but only if one additional condition would be met; that the landowners would be entitled to receive compensation due to such interference with the right to private property. Namely, if the legisla- tor or the Government with its regulations which, in determining the method of property enjoyment in accordance with Article 67 of the Constitution, interferes with the right to private property to the extent that it renders this right completely void (thus preventing the owner from using it for their benefit) and if the owner is left with only a bare right ("nuda proprietas"), such interventions should be considered as expropriating interventions. Thus, if an intervention of power in the ownership right is such as to render the entitlements which constitute the ownership right completely void, such an intervention must be regarded as expropriation. Such expropriation intervention must not be implemented based on a regulation or other general measure, but only on a case-by-case basis according to an expropriation procedure and against payment of compensation or remuneration in kind.

There are self-sufficiency possibilities (Table 1 - the production and reserves of mineral resources) that cannot be fully used due to the Regulation. This is paradoxically contrary to the national environmental legislation that defines economic and financial instruments for the protection of the environment. These instruments are, in our opinion, significantly larger when the same unit of mineral resource requires drilling and blasting operations, transportation around raw material exploration sites (which represents up to $30 \%$ of the cost price for one unit of raw material; POGAČNIK, 2011), and longer transport distances from the exploration site to the user.

Therefore, based on the above, suitable research methods for the verification of the actual depth of groundwater presence on alluvial plains must be established before the beginning of mining works which, according to the national legislation, also include research activities, the purpose of which is to determine the existence, position, and form of mineral deposits, their quality, quantity, and conditions for their exploitation. This includes the use of suitable complementary 3D geophysical techniques for groundwater detection, such as the GPR method (OLIVIERA, 2019; UZOIJE et al., 2019; PETERSON et al., 2020; ZAJC \& URBANC, 2019) or Seismic Electrical Resistivity Tomography ERT (ACCIANO et al., 2019; CHIEMEKE \& FELIX, 2019; DRASKOWITZ et al., 1995; SAAD et al., 2012; REDHAOUNIA et al., 2015) which ensure sound results. Of course, such research methods must always be referenced with specific data (MOLLEMA \& ANTONELLINI, 2016; VOULVOULIS et al., 2017), which can be retrieved from the research on existing infrastructure used to monitor the presence of groundwater level, its quality and, most importantly, management (VOULVOULIS et al., 2017; JOVIČIĆ et al., 2009). In addition, there are a number of computer tools available to analyse data that enable production

Table 2. A representation of the co-decision method according to the vertical and horizontal component, including all stakeholders involved in the co-decision process of determining the location of the exploration site and its management based on environmental and spatial laws.

\begin{tabular}{lll}
\hline \multicolumn{1}{c}{ Mining Act (ZRud-1) } & $\begin{array}{c}\text { Environmental Protection Act (ZVO) and its } \\
\text { implementing regulations }\end{array}$ & $\begin{array}{c}\text { Spatial Management Act (ZUreP) } \\
\text { and Spatial Planning Act (ZPNačrt) }\end{array}$ \\
\hline $\begin{array}{l}\text { Considering expert suggestions and strategic } \\
\text { documents, it indicates the location of the raw materials } \\
\text { and suggests technical methods for their extraction. }\end{array}$ & $\begin{array}{l}\text { Gives amended guidelines or assesses the } \\
\text { appropriateness of performing mining } \\
\text { works (given the applied technical } \\
\text { methods) considering the presence of } \\
\text { groundwater. }\end{array}$ & $\begin{array}{l}\text { When the works are acceptable and therefore the purpose of the } \\
\text { land use and its consequences (changing the morphology for a } \\
\text { more rational use of the surface of the area), only those areas are } \\
\text { included, which allow for a safe exploitation of mineral resources } \\
\text { and thus provide self-sufficiency to the local community. }\end{array}$ \\
\hline $\begin{array}{l}\text { Improvement of research techniques and technological } \\
\text { mining procedures with the purpose of obtaining data } \\
\text { of improved quality and to reduce to a minimum the } \\
\text { negative impact per unit of the space where works are } \\
\text { performed to exploit natural resources. }\end{array}$ & $\begin{array}{l}\text { Observing and managing environmental } \\
\text { protection on the micro area of the } \\
\text { exploration site and at local level } \\
\text { (traceability of groundwater quality). }\end{array}$ & $\begin{array}{l}\text { Active involvement of the local community (spatial planners and } \\
\text { local politics) in the process of co-decision regarding the } \\
\text { transformation and further use of the territory. }\end{array}$ \\
\hline
\end{tabular}



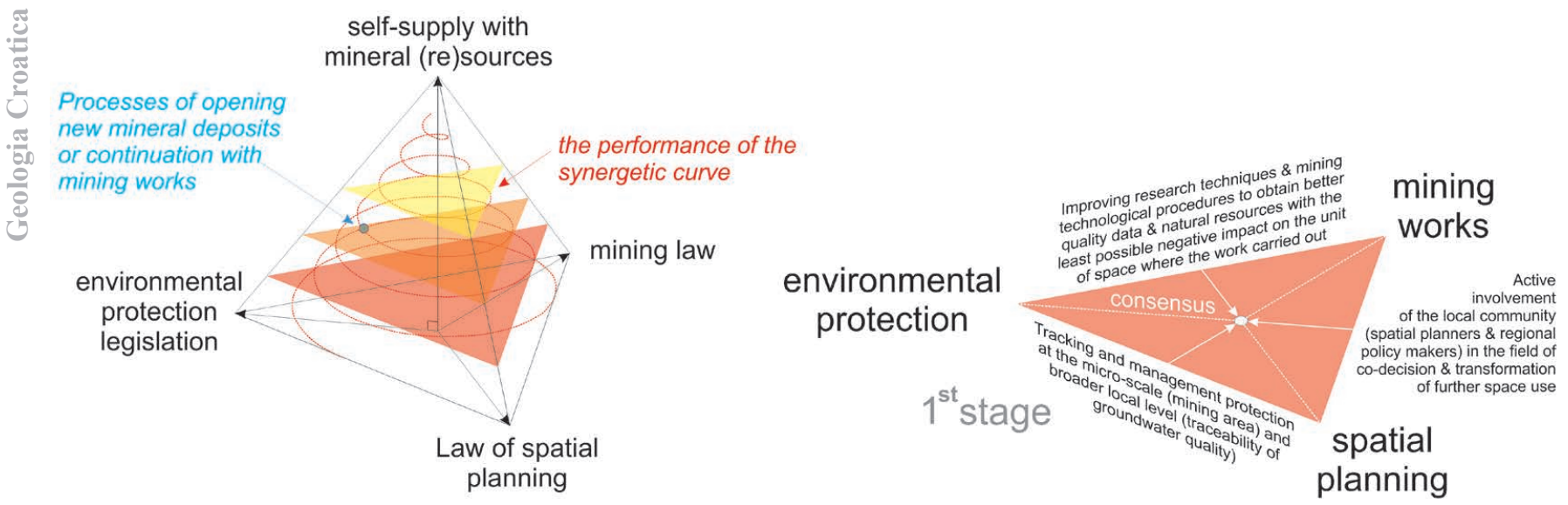

Figure 8. The Tetrahedral method of achieving agreement considering the structure of the stakeholders included in the decision-making procedure.

of a more accurate cartographic basis which, in addition to those mentioned above, also include the ModFlow tool (IZADY et al., 2017).

To achieve synergy in providing enough mineral resources and protecting the environment, we suggest the interdisciplinary approach provided for by the tetrahedral co-decision method (Table 2, Figure 8). In the process of confirming a new extraction location as part of a detailed spatial plan process, such an approach enables the investor and other stakeholders included in area management and environmental protection to obtain an overview of the current condition, technology used, and the impact of the works on a space unit where the natural resource is being extracted.

\section{CONCLUSION}

We accept that the protection of groundwater on an alluvial aquifer is necessary and appropriate. Regarding this, we shed light on issues arising from the implementation of the EU Decree in the national legal system. As shown, Slovenia opted for a very restrictive implementation that virtually disables the exploitation of mineral resources in shallow alluvial aquifers in the north eastern part of Slovenia, which indirectly prevents self-sufficiency in natural resources (aggregate-technical stone) suitable for construction use.

In our opinion, the implementation raises a constitutional issue due to the breach of several articles of the Constitution. The implementation has been performed with a Governmental Decree which, in its content, expresses its position on the issue, which is not allowed by law. The Decree interferes with ownership rights and limits the rights already granted, without awarding the right to compensation for the injured parties.

In addition, the implementation does not provide consistent methodology records and a consistent method of establishing sufficient non-protected zones above the section of the aquifer, saturated with groundwater (Figures 4 and 5). The content of the Decree is worded in a way to protect groundwater by imposing bans and causing damage to concessionaires, regardless of the impacts of single spatial interventions. Such implementation fails to distinguish between various hydrogeological properties and the impacts of gravel pits connected to these. The implementation should be carried out through a law defining the necessary limitations set up based on expert background from cartographic bases and considering the tetrahedral method of achieving agreement, which gives equal weight to selecting the location of the exploration site, environmental protection, and the performance of mining works.

We are of the opinion that a systematic and expert approach should be employed to determine the maximum amount of open area, determine the technology to extract mineral resources with the minimal impact on groundwater quality, and lay down other measures aimed at maintaining groundwater levels, especially on riverbeds that in Slovenia have mostly been modified by human intervention.

\section{REFERENCES}

ACCIANO, F., BUSETTI, M., BÖHM, G., BARADELLO, L., AFFATATO, A., DAL CIN M. \& NIETO, D. (2019): Geophysical investigation of the Isonzo Plain (NE Italy): imaging of the Dinaric-Alpine chain convergence zone.- Ital. J. Geosci., Vol. 138, 202-215. doi: 10.3301/IJG.2019.01

BRILLY, M. \& VIŽINTIN, G. (2011): Konceptualni model za Dravsko Ptujsko polje BOBER, mejnik 2, Poročilo P1B, Ekspertno numerični sistem za podporo odločanju na aluvijalnih telesih podzemnih voda Slovenije [The conceptual model for the Drava Ptujsko polje - BOBER, milestone 2. Report P1B, Expert numerical system for a groundwater decision support in alluvial bodies of Slovenia - in Slovenian].- Unpubl. report, Ljubljana, 35 p.

BREZNIK, M. \& ŽLEBNIK, L. (1961): Geological conditions along the Drava river between Maribor and Ptuj with special regard to the construction of water power plants. Geologija, 61, 7, 146-169.

CHIEMEKE, C.C. \& FELIX, O.O. (2019): Evaluation of Seismological Activity and Site Characterization Using Seismic Tomography.- Earth Science, 129, 53048-53052.

ČENČUR, C., CELARC, B., VIŽINTIN, G., BRILLY, M. \& VIDMAR, A. (2013): BOBER - Boljša Opazovanja za Boljše Ekološke Rešitve, Izdelava modelskih orodij za spremljanje suše, ocenjevanje stanja podzemnih voda in prognoziranje dinamike morja, 3. sklop: Ekspertno numerični sistem za podporo odločanju na aluvijalnih telesih podzemnih voda Slovenije, Kalibracija in validacija numeričnega modela toka podzemne vode za Dravsko in Ptujsko polje in izdelava poročila P3B, ARSO [BOBER - Better Observations for Better Ecological Solutions, Development of model tools for drought monitoring, assessment of groundwater status and forecasting of sea dynamics, Lot 3: Expert numerical system for decision support on alluvial bodies of groundwater in Slovenia, Calibration and validation of a $\mathrm{nu}$ merical model for the Drava and Ptuj alluvial field and preparation of $P 3 B$ report - in Slovenian].- Unpubl. report, ARSO, Ljubljana, 150 p.

DRASKOWITZ, P., MAGYAR, B. \& PATTANTYÙS-Á, M. (1995): Geophysical methods in groundwater prospecting and environmental protection.- Fisica de la Tiera, $\mathrm{N}^{\circ} 7,53-86$

DUBIŃSKI, J. (2013): Sustainable development of mining mineral resources.- Journal of Sustainable Mining, Vol. 12, No. 1, 1-6. doi: 10.7424/jsm130102

DIRECTIVE; Official Journal of the European Union L 372/19, 27.12.2006. doi: $10.7424 / \mathrm{jsm} 130102$

HENCKENS, M.L.C.M., VAN IERLAND E.C., DRIESSEN, P.P.J. \& WORRELL, E. (2016): Mineral resources: Geological scarcity, market price trends, and future generations.- Resources Policy, 49, 102-111. doi: 10.1016/j.resourpol.2016.04.012

IZADY, A., ABDALLA, O., JOODAVI, A. \& CHEN, M. (2017): Groundwater Modeling and Sustainability of a Transboundary Hardrock-Alluvium Aquifer in North Oman Mountains.- Water, 9, 161. doi: 10.3390/w9030161 
JOVIČIĆ, V., ŠUŠTERŠIČ, J. \& VUKELIČ, Ž. (20096): The application of fibre reinforced shotcrete as primary support for a tunnel in flysch.- In: Tunnelling and underground space technology, 24/6, 723-730.

KUDEŁKO, J., WANIEKISTA, K. \& WIRTH, H. (2013): Economic evaluation of mineral extraction projects from fields of exploitation during operational periods.- Journal of Sustainable Mining, Vol. 12, No. 1, 41-45. doi: 10.7424/jsm130108

MIOČ, P. \& ŽNIDARČIČ, M. (1987): Tolmač za lista Maribor in Leibniz, L 33-56 in L 33-44 [Basic Geological Map of SFRY 1:100000, Geology of the Maribor \& Leibniz sheet - in Slovenian].-Zvezni geološki zavod, Beograd, 58 p.

MOLLEMA P. N. \& ANTONELLINI, M. (2016): Water and (bio)chemical cycling in gravel pit lakes: A review and outlook.- Earth-Science Reviews, 159, 247-270. doi: 10.1016/j.earscirev.2016.05.006

OGRIN, D. (1996): Climate types in Slovenia.- Geografski vestnil, 68, 39-56.

OLIVIERA, M.A. (2019): GPR stratigraphy and quaternary morphogenesis in the semiarid Brazil.- Mercator, Fortaleza, v.18. doi: 10.4215/rm2018.e18027

PETTERSSON, M., OKSANEN, A., MINGALEVA, T., PETROV, V. \& MASLOBOEV, V. (2015): License to Mine: A Comparison of the Scope of the Environmental Assessment in Sweden, Finland and Russia.- Natural Resources, 6, 237-255. doi: 10.4236/nr.2015.64022

PETERSON, C.D., JOL, H.M., PERCY, D. \& PERKINS, R. (2020): Use of Ground Penetrating Radar, Hydrogeochemical Testing, and Aquifer Characterization to Establish Shallow Groundwater Supply to the Rehabilitated Ni-les'tun Unit Floodplain: Bandon Marsh, Coquille Estuary, Oregon, USA.- Journal of Geography and Geology, 12/1, 25-49. doi: 10.5539/jgg.v12n1p25

POGAČNIK, Ž. (2011): Recycled construction materials as supplemental raw materials for the OPC clinker production in Salonit Anhovo.- In: ŽIBRET, G. \&. ŠOLAR, S.V. (eds.): Sustainable aggregates resource management: international conference, September 20-22, 2011, Ljubljana, Slovenia: abstract and short paper book. Ljubljana: Geological Survey of Slovenia, 2011, 24-25.

REDHAOUNIA, B., ILONDO, B.O., GABTNI, H., SAMI, K. \& BÉDIR, M. (2015): Electrical Resistivity Tomography (ERT) Applied to Karst Carbonate Aquifers: Case Study from Amdoun, Northwestern Tunisia.- Pure Appl. Geophys. doi: 10.1007/s00024-015-1173-Z

SAAD, R., NAWAWI, M.N.M. \& MOHAMAD, E.T. (2012): Groundwater Detection in Alluvium Using 2-D Electrical Resistivity Tomography (ERT).- Electronic Journal of Geotechnical Engineering, Vol. 17, 369-376.

SENEGAČNIK, A., BURGER, A. \& ŠTIH, J. (2019): Stanje na področju mineralnih surovin v Sloveniji v letu 2018 [Situation in the field of mineral resources in Slovenia in 2018 - in Slovenian].- Mineralne surovine, 15/1, 12-24.
SUPOVEC, I. (2004): Hidrogeološko poročilo za potrebe izdelave programa monitoringa podzemnih vod na območju odlagališča nenevarnih odpadkov Gajke pri Ptuju [Hydrogeological report for the needs of the preparation of the groundwater monitoring program in the area of the non-hazardous waste landfill Gajke near $P t u j$ - in Slovenian].- Unpubl. report, HGEM d.o.o., Ljubljana, 50 p.

TANCAR, M., SUPOVEC, I., VIŽINTIN, G. \& PUČKO, T. (2009a): Geološko, tehnično in hidrogeološko poročilo o izvedbi dveh piezometrov na lokaciji VMP Dornava. [Geological, technical and hydrogeological report on the implementation of two piezometers at the VMP Dornava site - in Slovenian].- Unpubl. report, HGEM d.o.o., Ljubljana, $69 \mathrm{p}$

TANCAR, M., SUPOVEC, I. \& VIŽINTIN, G. (2009b): Geološko, tehnično in hidrogeološko poročilo o izvedbi dveh piezometrov na lokaciji VMP Gerečja vas [Geological, technical and hydrogeological report on the implementation of two piezometers at the VMP Gerečja vas site - in Slovenian].- Unpubl. report, HGEM d.o.o., Ljubljana, $68 \mathrm{p}$

UZOIJE, A.P., CHRYSOGONUS NWAIGWE, C. \& BRIGHT, N. (2019): Vulnerability Assessment of a Sand-rich Alluvium; A DRASTIC Model Approach.- International Journal of Scientific \& Engineering Research, Vol. 10, Issue 5, 1398-1428.

VOULVOULIS, N., ARPON, K.D. \& GIAKOUMIS, T. (2017): The EU Water Framework Directive: From great expectations to problems with implementation.- Science of the Total Environment, 575, 358-366. doi: 10.1016/j.scitotenv.2016.09.228

VUKELIČ, Ž. \& VULIĆ, M. (2014): Ocena in natančnost ocene 3D-položaja točk v vrtini [Evaluation of $3 D$ positions and the positional accuracy of points within a borehole - in Slovenian].- Geodetski vestnik: glasilo Zveze geodetov Slovenije, $58 / 2,327-341$

WATERLOO HYDROGEOLOGIC (2011): Visual MODFLOW 2011.1 User's Manual.Waterloo Hydrogeologic. Retrieved 03.07.2020.

ZAJC, M. \& URBANC, J. (2019): Using GPR on a Problematic Agricultural Field for Groundwater Protection in a Karst Environment. Near Surface Geoscience Conference \& Exhibition 2019, 8-12 September 2019, The Hague, Netherlands.

ZRud-1; Mining Act (Official Gazette of RS, No. 14/14 and 61/17 - GZ)

ZV-1; The Water Act (Official Gazette of RS, No. 67/02, 2/04 - ZZdrI-A, 41/04 - ZVO$1,57 / 08,57 / 12,100 / 13,40 / 14,56 / 15$ and $65 / 20)$.

ŽELEZNIKAR, V. (2015): Mining project for obtaining a concession for exploitation with an estimate of the amount of rehabilitation costs after final exploitation.Monograph, No. 1-8 / 2014-VŽ, August, 62 p.

ŽLEBNIK, L. (1982): Hidrogeološke razmere na Dravskem polju [Hydrogeological conditions in the Drava plain - in Slovenian].- Geologija, 82, 25/1, 151-164. 